\title{
Exposure as Collected Link Group
}

National Cancer Institute

\section{Source}

National Cancer Institute. Exposure as Collected Link Group. NCI Thesaurus. Code C117472.

A sequence of characters used to link multiple collected exposure records to a single finding. 